\title{
Modeling the Seismic Source and Tsunami Generation of the December 12, 1992 Flores Island, Indonesia, Earthquake
}

\author{
Dannie Hidayat, ${ }^{1}$ Jeffrey S. BARker, ${ }^{1}$ and Kenji Satake ${ }^{2}$
}

\begin{abstract}
On December 12, 1992 a large earthquake $\left(M_{s} 7.5\right)$ occurred just north of Flores Island, Indonesia which, along with the tsunami it generated, killed more than 2,000 people. In this study, teleseismic $P$ and $S H$ waves, as well as $P P$ waves from distances up to $123^{\circ}$, are inverted for the orientations and time histories of multiple point sources. By repeating the inversion for reasonable values of depth, time separation and spatial separation, a 2-fault model is developed. Next, the vertical deformation of the seafloor is estimated from this fault model. Using a detailed bathymetric model, linear and nonlinear tsunami propagation models are tested. The data consist of a single tide gauge record at Palopo (650 $\mathrm{km}$ to the north), as well as tsunami runup height measurements from Flores Island and nearby islands. Assuming a tsunami runup amplification factor of two, the two-fault model explains the tide gauge record and the tsunami runup heights on most of Flores Island. It cannot, however, explain the large tsunami runup heights observed near Leworahang (on Hading Bay) and Riangkroko (on the northeast peninsula). Massive coastal slumping was observed at both of these locations. A final model, which in addition to the two faults, includes point sources of large vertical displacement at these two locations explains the observations quite well.
\end{abstract}

Key words: Earthquake source, body waves, moment tensor, tsunami modeling, submarine slumps, Indonesia.

\section{Introduction}

The December 12, 1992 Flores Island, Indonesia, earthquake $\left(M_{s} 7.5\right)$ and the ensuing tsunami caused over 2,000 deaths and another 2,000 injuries (Figure 1). Tsunami runup heights along the northern shore of Flores Island vary from $2-5 \mathrm{~m}$ in the central portion of the island to as much as $26 \mathrm{~m}$ in the eastern portion (YEH et al., 1993; Tsuj and MAtsutomi, 1993; TsuJi et al., 1995). The tsunami washed away entire villages on Flores Island and on the small Babi Island just offshore.

Indonesia is the site of many large earthquakes, with the Indo-Australian plate subducting northward beneath the Eurasian plate. The shallow depth of the Flores Island earthquake ( $36 \mathrm{~km}$, PDE; $15 \mathrm{~km}$, Harvard CMT; $9 \mathrm{~km}$, this study), however, \footnotetext{
U.S.A.

' Department of Geological Sciences, State University of New York, Binghamton, NY 13902-6000,

2 Department of Geological Sciences, University of Michigan, Ann Arbor, MI 48109-1063, U.S.A.
} 


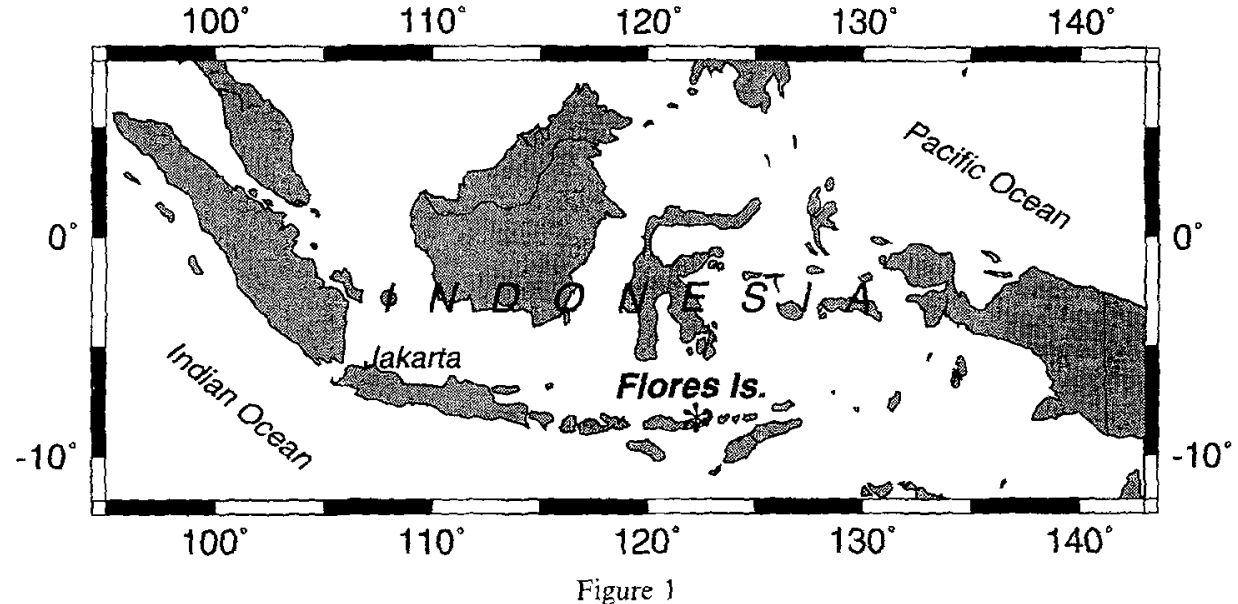

Map of Indonesia showing the location of the December 12, 1992 Flores Island earthquake.

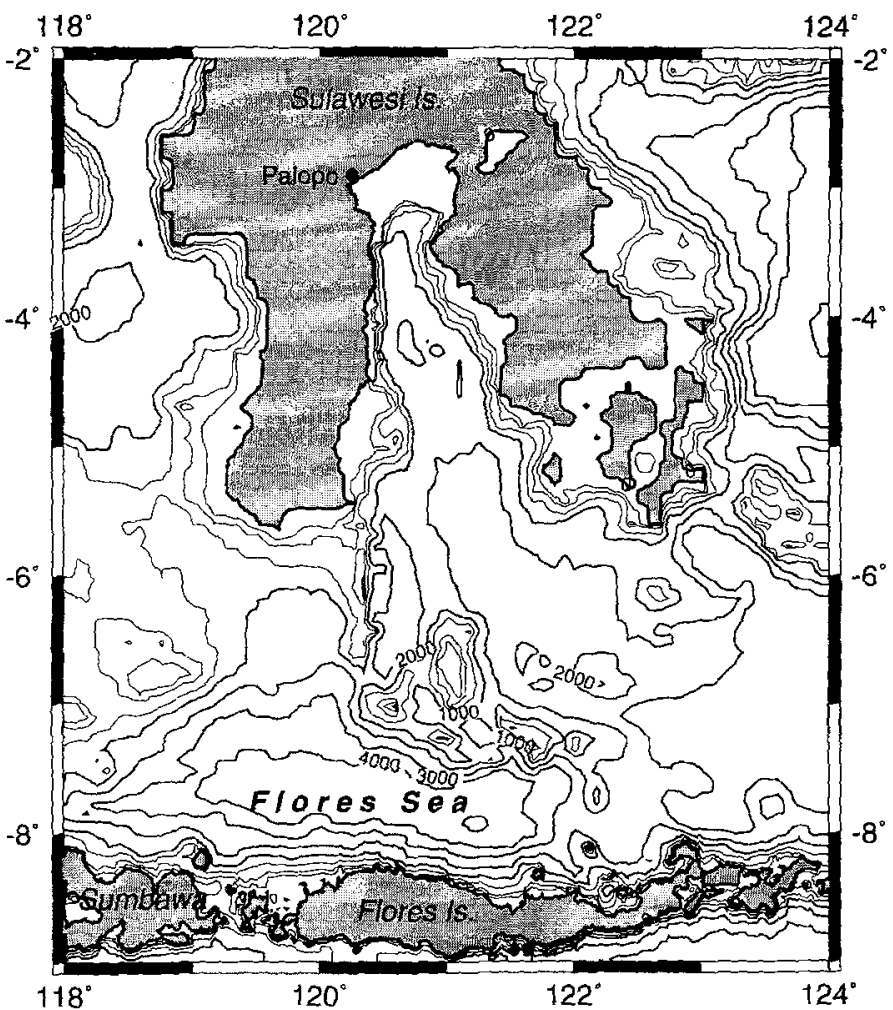

Figure 2

Regional bathymetry model based on edited ETOPO-5 data augmented with detailed information from nautical charts near the north coast of Flores Island and near the tide gauge at Palopo on Sulawesi Island. Contours show bathymetric depth in meters. 
indicates that it occurred in the backarc region of the Eurasian lithosphere above the subducting slab. Other studies (HARVARD CMT; IMAMURA and KIKUCHI, 1994; BECKERS and LAY, 1995) as well as this study, suggest a thrust mechanism on a shallow-dipping fault plane dipping to the south, consistent with backarc tectonics (for example, PlafKer and WARD, 1992).

In this study, we invert teleseismic, broadband $P$ and $S H$ waves, as well as $P P$ waves (from ranges up to $123^{\circ}$ ) for the seismic moment rate tensor. We resolve two independent subsources, with the second located to the east of the first. From the seismological model, we estimate the vertical displacement of the seafloor. Using linear and nonlinear methods, we then compute the tsunami generation and propagation. Only one tide gauge recorded the tsunami, at Palopo on southern Sulawesi, $650 \mathrm{~km}$ north of Flores Island (Figure 2). Our tsunami models are constrained to fit this record, while attempting to explain the tsunami runup heights measured on Flores Island. We find that substantial secondary (nonseismic) sources are required to explain the extremely large tsunami runups on the eastern portion of Flores Island, and model these in terms of landslides or submarine slumps.

\section{Modeling the Seismic Source}

Teleseismic broadband $P$ - and $S$-wave seismograms (ranges $30-90^{\circ}$ ) were obtained from the IRIS Data Management Center. The $S$ waves were rotated into the tangential component, then the $P$ and $S H$ waves were corrected for instrument gain and, where necessary, integrated to ground displacement. To improve the azimuthal distribution of data, $P P$ waves from ranges up to $123^{\circ}$ were also obtained and corrected to ground displacement. Nevertheless, azimuths from south to west are poorly sampled. The data were quite noisy at some stations, so phaseless (two-pass) Butterworth filters (high-pass for $P$ waves, low-pass for $S H$ waves) were applied. The data modeled in this study and details of filters applied are listed in Table 1.

Synthetic seismograms are computed using a propagator matrix method (KIKUCHI and KANAMORI, 1991). The seismic velocity structure at the source is assumed to consist of water and a four-layer oceanic crust overlying the mantle (Table 2). Similarly, the velocity structure near each receiver is assumed to be continental crust with two layers overlying the mantle. For the $P P$ waves, the structure near the bounce point is assumed to be the same as the oceanic structure at the source. The synthetic seismograms are computed for a triangular far-field source time function with vertical strike-slip, vertical dip-slip and compensated linear vector dipole (CLVD) sources, since the response due to an arbitrarily-oriented shear dislocation may be obtained from the linear combination of these three fundamental dislocations (LANGSTON and Helmberger, 1975). An attenuation operator with $t^{*}$ of 1.0 for $P$ waves, 4.0 for $S H$ waves, and 2.0 for $P P$ waves is applied. The displacement instrument response is convolved and, if necessary, 
Table 1

Seismic data and filter characteristics

\begin{tabular}{|c|c|c|c|c|c|}
\hline Station & $\begin{array}{c}\text { Distance } \\
\left(^{\circ}\right)\end{array}$ & $\begin{array}{l}\text { Azimuth } \\
\text { ( })\end{array}$ & $P$ & $P P$ & $S H$ \\
\hline BJI & 48.3 & 354.1 & + & & + \\
\hline CHTO & 35.1 & 320.0 & ++ & & ++ \\
\hline ENH & 40.1 & 343.2 & + & & \\
\hline HIA & 57.2 & 358.3 & + & & + \\
\hline KIP & 83.8 & 67.4 & $++^{1}$ & & \\
\hline KMI & 38.0 & 331.1 & + & & \\
\hline KONO & 108.2 & 330.4 & & $++^{1}$ & \\
\hline LSA & 47.9 & 323.2 & + & & \\
\hline MAJO & 47.1 & 18.0 & ++ & & \\
\hline MDJ & 53.0 & 6.9 & + & & + \\
\hline PAB & 122.8 & 312.1 & & $++^{1}$ & \\
\hline PAS & 119.3 & 53.8 & & $+t^{1.3}$ & \\
\hline RAR & 76.2 & 109.8 & $++^{1}$ & & $+t^{2}$ \\
\hline SNZO & 57.0 & 134.3 & ++ & & ++ \\
\hline SPA & 81.8 & 180,0 & ++ & & $t+t^{2}$ \\
\hline SSE & 39.1 & 359.0 & + & & + \\
\hline TATO & 33.0 & 359.3 & ++ & & $++^{2}$ \\
\hline TAU & 41.1 & 151.4 & ++ & & \\
\hline YSS & 58.0 & 16.7 & ++ & & $+t^{2}$ \\
\hline
\end{tabular}

+ Used only in preliminary, 1-source inversions.

++ Used in 2-source inversions.

' Low-pass Butterworth filtered at $0.05 \mathrm{~Hz}$.

${ }^{2}$ High-pass Butterworth filtered at $0.02 \mathrm{~Hz}$.

${ }^{3}$ In preliminary inversions, a stack of Terrascope $P P$ waves was used; in final inversions, the observed $P P$ wave at PAS was used.

low-pass or high-pass filters are applied to obtain the Green's functions used in the inversion.

Prior to inversion, $P, P P$ and $S H$ wave windows are defined in the data, and synthetic seismograms for a starting model are aligned in time with the observed waveforms. After defining the time window of interest, the waveforms are inverted for the deviatoric moment rate tensors and far-field source time functions of one or more sources, varying the depths, relative locations and origin times of the sources. The moment tensor inversion method is given in LANGSTON (1981), with applications to teleseismic body waves in BARKER and LANGSTON $(1981,1982,1983)$. The source centroid depth is determined by repeating the inversion using Green's functions computed for different depths, and selecting the depth that minimizes the difference between observed and synthetic seismograms (as measured by the RMS fit).

One-source Model. An initial inversion was performed using as a starting model the Harvard CMT orientation, and a source time function consisting of 11 overlapping isosceles triangles of equal amplitude. Each triangle has a rise and fall 
Table 2

Seismic velocity structures

\begin{tabular}{|c|c|c|c|}
\hline \multicolumn{4}{|c|}{ Oceanic Structure (at source and $P P$ bounce points) } \\
\hline $\begin{array}{c}V_{P} \\
(\mathrm{~km} / \mathrm{s})\end{array}$ & $\begin{array}{c}V_{S} \\
(\mathrm{~km} / \mathrm{s})\end{array}$ & $\begin{array}{l}\text { Density } \\
\left(\mathrm{g} / \mathrm{cm}^{3}\right)\end{array}$ & $\begin{array}{l}\text { Thickness } \\
(\mathrm{km})\end{array}$ \\
\hline 1.50 & 0.00 & 1.03 & 1.5 \\
\hline 2.00 & 1.15 & 1.80 & 1.0 \\
\hline 4.75 & 2.75 & 2.30 & 3.0 \\
\hline 6.52 & 3.75 & 2.50 & 3.0 \\
\hline 7.00 & 4.00 & 2.80 & 5.0 \\
\hline 8.00 & 4.60 & 3.10 & h.s. \\
\hline \multicolumn{4}{|c|}{ Continental Structure (at receivers) } \\
\hline $\begin{array}{c}V_{P} \\
(\mathrm{~km} / \mathrm{s})\end{array}$ & $\begin{array}{c}V_{S} \\
(\mathrm{~km} / \mathrm{s})\end{array}$ & $\begin{array}{l}\text { Density } \\
\left(\mathrm{g} / \mathrm{cm}^{3}\right)\end{array}$ & $\begin{array}{c}\text { Thickness } \\
(\mathrm{km})\end{array}$ \\
\hline 6.00 & 3.46 & 2.60 & 15.0 \\
\hline 7.00 & 4.04 & 2.80 & 18.0 \\
\hline 8.00 & 4.62 & 3.10 & h.s. \\
\hline
\end{tabular}

time of $5 \mathrm{sec}$. After five iterations a solution was obtained with orientation consisting of a shallow-dipping reverse mechanism at a depth of $9 \mathrm{~km}$. This is substantially shallower than the depths listed in the PDE $(36 \mathrm{~km})$ and the Harvard CMT solution $(15 \mathrm{~km})$. The southward-dipping fault plane is preferred since this is consistent with the sense of motion expected in backarc compression (e.g., PLAFKER and WARD, 1992). The source time history has a duration of about $55 \mathrm{sec}$, and consists of two pulses, each of $20-25 \mathrm{sec}$ duration. This suggests that the earthquake has a double source, which we could interpret as two distinct asperities. The moment magnitude is calculated as 7.9 , with moment approximately equally distributed between the two pulses. In this case, a single-point source, which is implicitly assumed in the moment tensor inversion, may not be a valid model. We may, instead, consider two point sources, with distinct depths, orientations, and source time histories.

Two-source Inversion. In an attempt to distinguish the parameters of the two subsources, simultaneous inversions were performed, holding the depth of the first source at $9 \mathrm{~km}$ and varying the depth, horizontal separation and time separation of the second source. The starting orientation of each source was the one-source moment tensor, and the source time histories were parameterized by separate series of eight overlapping isosceles triangles, now with a rise and fall time of $3 \mathrm{sec}$. Since we are interested in the details of the source process, and since the data of the Chinese Digital Seismograph Network (CDSN) are sensitive only to lower frequencies, these stations were excluded from the 2-source inversions. There was no improvement in RMS fit when the second source was located at a different depth 

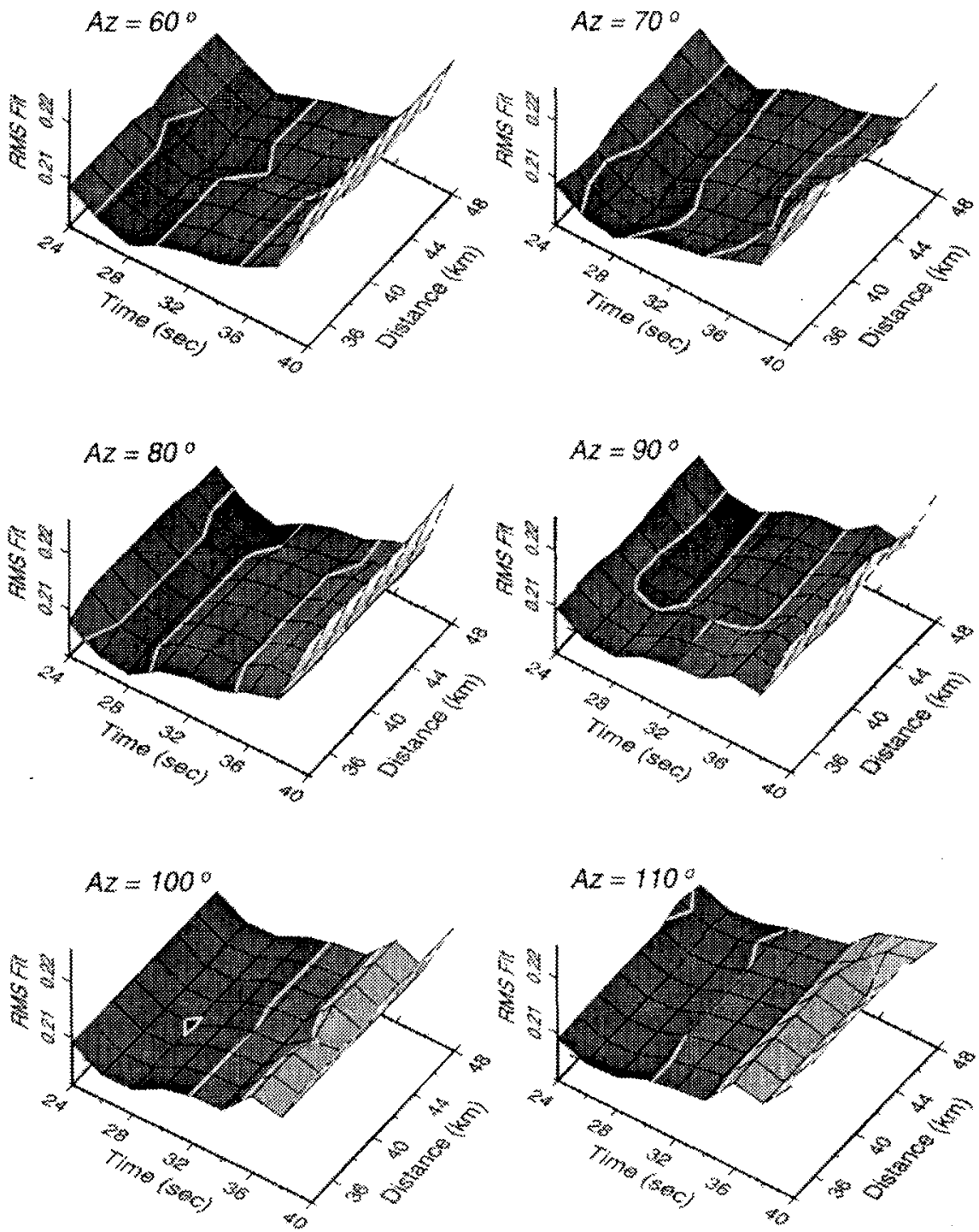

Figure 3

RMS fit (a measure of the residual between observed and synthetic seismograms) for various values of the distance, azimuth and time separation of the second source from the first. Time separation is well resolved at $28 \mathrm{sec}$. Azimuths from $60^{\circ}$ to $90^{\circ}$ yield good fits. Distance separation is poorly resolved, so we choose $40 \mathrm{~km}$.

than the first, so we will assume both to be at $9 \mathrm{~km}$ depth. Inversions were performed for horizontal spatial separations of $34-48 \mathrm{~km}$ between sources, with the second located at azimuths of $60-110^{\circ}$ from the first. Based on the one-source inversion result, time separations of $24-40 \mathrm{sec}$ were considered. Plots of RMS fit for each of these inversions are shown in Figure 3. Time separation is well resolved 


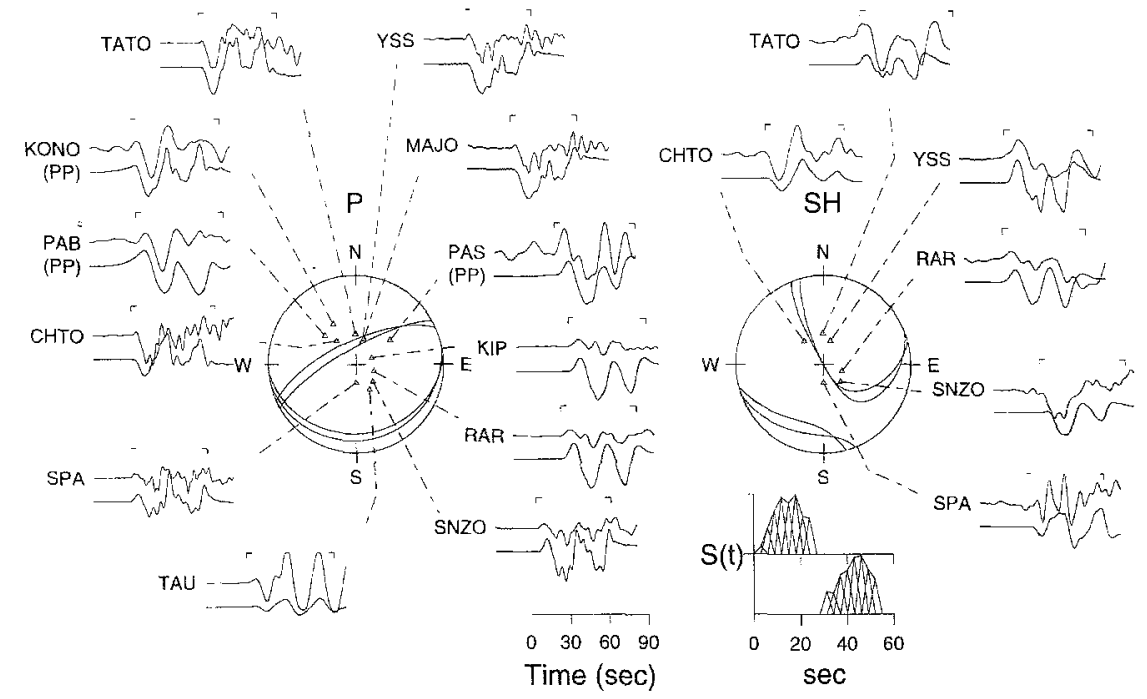

Figure 4

Inversion results for the preferred 2-source model. Observed (above) and synthetic (below) seismograms are shown plotted on common time and amplitude scales. The inversion time windows are indicated above the observed waveforms. Also shown are lower-hemisphere equal-area projections of the $P$ and SH nodal surfaces for the major double couple of each source, with each station's position in the radiation pattern indicated. The two-source time histories are shown on the bottom right of the figure, plotted on common time and amplitude scales.

as $28 \mathrm{sec}$, but the spatial separation is not at all well resolved. For the distances chosen, a slight minimum occurs at $38 \mathrm{~km}$ for an azimuth of $70^{\circ}$, however the resolution is so poor that we can conclude only that the second source occurred at some distance along an azimuth of $60-90^{\circ}$ from the first.

Figure 4 shows the waveforms and results for the two-source inversion, with the second source separated in time by $28 \mathrm{sec}$ and in space by $40 \mathrm{~km}$ at an azimuth of $80^{\circ}$ from the first. $P$ and $P P$ waves are shown on the left, and $S H$ waves on the right, along with the nodal surfaces corresponding to the major double couple for each source, on lower-hemisphere equal-area projections. For each station, the observed waveform is shown above the final synthetic waveform, plotted on common time and amplitude scales. The inversion time window is indicated above each observed trace. Although some of the data are still rather noisy, significant details of the $P, P P$ and $S H$ waveforms are well modeled. In particular, nodal and small amplitude $P$ waves to the north and west constrain the dip of the fault plane, while the $S H$ polarity change between $C H T O$ and TATO constrains the rake. $P P$ waves at $\mathrm{KONO}$ and $\mathrm{PAB}$ are dilatational, although the Hilbert transform results in an upward first motion. The two-source model allows details of later arrivals in $P$ waves (such as TATO, YSS, MAJO and SPA), $P P$ waves (such as PAS and PAB), and SH waves (such as CHTO, YSS and SPA) to be well modeled. The two source time functions are plotted at the bottom right of the figure. Each source 
Table 3

Seismic inversion results for the Flores Island earthquake

\begin{tabular}{|c|c|c|c|}
\hline & & First Source & Second Source \\
\hline \multirow{4}{*}{\multicolumn{2}{|c|}{$\begin{array}{l}\text { Depth } \\
\text { Time Separation } \\
\text { Spatial Separation }\end{array}$}} & $9 \mathrm{~km}$ & $9 \mathrm{~km}$ \\
\hline & & & $28 \mathrm{sec}$ \\
\hline & & & $40 \mathrm{~km}$ \\
\hline & & & $80^{\circ}$ azimuth \\
\hline Moment Tensor & $\mathrm{NN}$ & 3.15 & 1.95 \\
\hline \multirow{4}{*}{$\left(\times 10^{27}\right.$ dyne-cm $)$} & $\mathrm{EE}$ & 1.44 & 1.29 \\
\hline & $\mathrm{NE}$ & -0.016 & 0.0066 \\
\hline & ND & 3.51 & 3.87 \\
\hline & $E D$ & -2.16 & -2.46 \\
\hline \multicolumn{2}{|c|}{ Seismic Moment ( $\times 10^{27}$ dyne-cm) } & 5.8 & 5.4 \\
\hline \multicolumn{2}{|c|}{ Moment Magnitude } & 7.8 & 7.8 \\
\hline \multicolumn{2}{|c|}{$\begin{array}{l}\text { Major Double Couple Moment } \\
\left(\times 10^{27} \text { dyne-cm }\right)\end{array}$} & 5.61 & 5.22 \\
\hline \multicolumn{4}{|c|}{ Fault Planes: } \\
\hline \multirow[t]{3}{*}{1} & Strike $\left({ }^{\circ}\right)$ & 85 & 77 \\
\hline & $\operatorname{Dip}\left({ }^{\circ}\right)$ & 23 & 15 \\
\hline & Rake( $\left(^{\circ}\right)$ & 108 & 106 \\
\hline \multirow[t]{3}{*}{2} & Strike $\left(^{\circ}\right)$ & 246 & 241 \\
\hline & $\operatorname{Dip}\left({ }^{\circ}\right)$ & 68 & 76 \\
\hline & $\operatorname{Rake}\left({ }^{\circ}\right)$ & 83 & 86 \\
\hline \multicolumn{2}{|c|}{ Time function duration } & $28 \mathrm{sec}$ & $30 \mathrm{sec}$ \\
\hline
\end{tabular}

function has approximately equal duration and amplitude, indicating that the moment of the two sources is essentially the same. The final model parameters are listed in Table 3. Each source is a shallow-dipping reverse fault with moment magnitude 7.8 .

\section{Modeling Tsunami Generation}

Using the seismic inversion results, we may model the tsunami generated by the Flores Island earthquake. As mentioned in the introduction, only a single tide gauge recorded a significant tsunami signal, and this was located $650 \mathrm{~km}$ away at Palopo, on the island of Sulawesi. Other tide gauges in the region either do not record continuously, or were shadowed by land (GoNZÁlez et al., 1993). An international survey team measured a number of tsunami runup heights along the northeast coast of Flores Island within three weeks of the earthquake (YEH et al., 1993; Tsuji and MAtsutomi, 1993; Tsuji et al., 1995). They measured maximum tsunami runup heights and inundation areas at several villages. These measurements were supported by aerial photography and geodetic measurements (GoNZÁLEZ et al., 1993). At each location we consider the largest consistent measurement 
Table 4

Observed and calculated ${ }^{*}$ tsunami runup heights (in $m$ )

\begin{tabular}{|c|c|c|c|c|c|c|c|c|}
\hline \multirow[b]{2}{*}{ \# } & \multirow[b]{2}{*}{ Station Name } & \multirow[b]{2}{*}{ Latitude } & \multirow[b]{2}{*}{ Longitude } & \multirow[b]{2}{*}{ Observed } & \multicolumn{2}{|c|}{ Linear model } & \multicolumn{2}{|c|}{ Nonlinear model } \\
\hline & & & & & 2 faults & +2 slumps & 2 faults & +2 slumps \\
\hline 1 & Mage, Palu Is. & -8.30 & 121.75 & 2.8 & 1.79 & 1.79 & 1.80 & 1.80 \\
\hline 2 & Mausanbi & -8.50 & 121.78 & 3.4 & 3.15 & 3.04 & 2.88 & 2.88 \\
\hline 3 & Awora & -8.48 & 121.85 & 2.9 & 2.90 & 2.74 & 2.68 & 2.68 \\
\hline 4 & Deteh & -8.53 & 122.03 & 2.3 & 5.88 & 5.88 & 5.46 & 5.46 \\
\hline 5 & Kolisia & -8.53 & 122.10 & 5.2 & 5.52 & 5.52 & 5.40 & 5.40 \\
\hline 6 & Nagasarong & -8.53 & 122.12 & 4.9 & 5.11 & 5.00 & 4.86 & 4.88 \\
\hline 7 & Waturia & -8.53 & 122.13 & 2.9 & 4.18 & 4.15 & 3.64 & 4.08 \\
\hline 8 & Patisomba & -8.55 & 122.15 & 4.0 & 4.11 & 4.61 & 4.06 & 4.06 \\
\hline 9 & Nangahureh & -8.55 & 122.17 & 1.9 & 3.44 & 3.30 & 3.30 & 3.30 \\
\hline 10 & Wailiti & -8.57 & 122.18 & 2.1 & 3.43 & 3.21 & 2.16 & 2.62 \\
\hline 11 & Wuring & -8.60 & 122.20 & 3.2 & 3.67 & 3.58 & 2.68 & 2.90 \\
\hline 12 & Maumere & -8.62 & 122.23 & 3.0 & 2.95 & 3.14 & 2.24 & 2.46 \\
\hline 13 & Waioti & -8.63 & 122.27 & 2.5 & 3.46 & 3.60 & 3.02 & 3.02 \\
\hline 14 & Geliking & -8.63 & 122.28 & 3.3 & 3.63 & 3.94 & 3.28 & 3.16 \\
\hline 15 & Kewapante & -8.63 & 122.30 & 0.6 & 3.02 & 3.13 & 2.70 & 2.70 \\
\hline 16 & Egon & -8.60 & 122.42 & 1.8 & 4.05 & 4.22 & 3.98 & 3.98 \\
\hline 17 & Wodung & -8.58 & 122.48 & 2.3 & 4.69 & 5.34 & 3.58 & 3.86 \\
\hline 18 & Nangahale & -8.55 & 122.50 & 1.5 & 3.58 & 5.26 & 3.70 & 3.38 \\
\hline 19 & Talobura & -8.52 & 122.52 & 2.4 & 5.52 & 6.11 & 4.92 & 4.74 \\
\hline 20 & Ngolo, Pomana Is. & -8.35 & 122.32 & 3.2 & 1.97 & 2.58 & 1.98 & 1.98 \\
\hline 21 & Buton, Pomana Is. & -8.33 & 122.33 & 1.5 & 2.23 & 2.23 & 2.24 & 2.24 \\
\hline 22 & Taot, Desar Is. & -8.87 & 122.35 & 2.8 & 1.33 & 2.02 & 1.20 & 1.32 \\
\hline 23 & Kusung, Besar Is. & -8.87 & 122.42 & 4.1 & 2.62 & 4.64 & 2.66 & 3.92 \\
\hline 24 & Permahan Is. & -8.45 & 122.45 & 3.4 & 3.21 & 4.46 & 3.16 & 2.74 \\
\hline 25 & Babi Is. $N$ & -8.40 & 122.52 & 4.0 & 2.12 & 3.01 & 2.14 & 2.36 \\
\hline 26 & Babi Is. W & -8.42 & 122.50 & 7.1 & 2.40 & 3.62 & 2.40 & 2.40 \\
\hline 27 & Babi Is. S & -8.43 & 122.52 & 4.0 & 3.76 & 2.94 & 3.72 & 3.72 \\
\hline 28 & Babi Is. E & -8.42 & 122.53 & 5.6 & 2.69 & 2.94 & 2.66 & 2.66 \\
\hline 29 & Nebe & -8.45 & 122.53 & 4.6 & 5.11 & 5.40 & 3.04 & 3.04 \\
\hline 30 & Wailamung & -8.42 & 122.58 & 5.5 & 6.92 & 7.81 & 5.42 & 4.80 \\
\hline 31 & Larentuka & -8.37 & 122.98 & 1.8 & 1.97 & 1.96 & 1.70 & 1.70 \\
\hline 32 & Pantai Lato & -8.37 & 122.77 & 3.8 & 3.59 & 5.78 & 3.12 & 3.52 \\
\hline 33 & Uepadung & -8.30 & 122.83 & 11.0 & 3.44 & 10.27 & 3.12 & 5.66 \\
\hline 34 & Waibalen & -8.28 & 122.88 & 10.6 & 4.42 & 10.70 & 3.30 & 8.16 \\
\hline 35 & Pantai Lela & -8.20 & 122.83 & 4.5 & 3.83 & 6.52 & 3.52 & 4.38 \\
\hline 36 & Riangkroko & -8.15 & 122.78 & 18.4 & 3.31 & 11.14 & 3.24 & 14.20 \\
\hline 37 & Bunga & -8.10 & 122.80 & 12.3 & 2.70 & 8.00 & 2.70 & 2.94 \\
\hline
\end{tabular}

* Calculated as $2.0 \times$ computed tsunami height.

of tsunami runup height (see Table 4). These tsunami runup height measurements, combined with the tide gauge record at Palopo, serve as our data set. Tsunami runup heights are generally larger than tsunami wave amplitudes (as would be measured on tide gauges) by an amount that depends on the coastal topography and wave dynamics. Furthermore, computed tsunami heights depend on the grid 
size of the bathymetric model (SATAKe and TANIOKA, 1995). In this study, we assume a uniform amplification factor of two in modeling maximum tsunami runup heights on Flores Island.

Our model for the bathymetry is initially based on edited ETOPO-5 data, augmented with detailed bathymetry compiled from nautical charts near Flores Island and along the bay leading to Palopo. Particular attention is paid to coastlines and shallow water. The coastal water around Flores Island is generally deep (at least $20 \mathrm{~m}$ ), whereas it is much shallower near the Palopo tide gauge station $(6 \mathrm{~m})$. The result is sampled onto a bathymetric grid with one minute increments from $118^{\circ} \mathrm{E}$ to $124^{\circ} \mathrm{E}$ longitude and $2^{\circ} \mathrm{S}$ to $9^{\circ} \mathrm{S}$ latitude (Figure 2).

The next step is to model the vertical deformation of the seafloor as a result of the earthquake, using the method by OKADA (1985). We use seismicity and geodetic observations to construct a fault model based on our seismic inversion results. Aftershock seismicity (located by the U.S.G.S.) ranges in depth from the surface to about $15 \mathrm{~km}$ depth. For the dip determined in the inversion, this yields a down-dip width of the fault of $40 \mathrm{~km}$. If we assume an aspect ratio of 2, typical of large earthquakes (KANAMORI and ANDERSON, 1975; GELLER, 1976), the length of each source is assumed to be $80 \mathrm{~km}$. If the second source is separated from the first by $40 \mathrm{~km}$, as suggested by the seismic inversion, the two faults would overlap over half their area. On the other hand, noting that the spatial separation is poorly resolved in the inversion, the horizontal distribution of seismicity is better matched if the second source is moved so that it is $80 \mathrm{~km}$ from the first. Thus, fixing the bottom center of the first source at the location of the hypocenter published in the PDE, the surface projection of the fault plane occurs at the location of the heavy line on the left side of Figure 5. The center of the top of the second source is located $80 \mathrm{~km}$

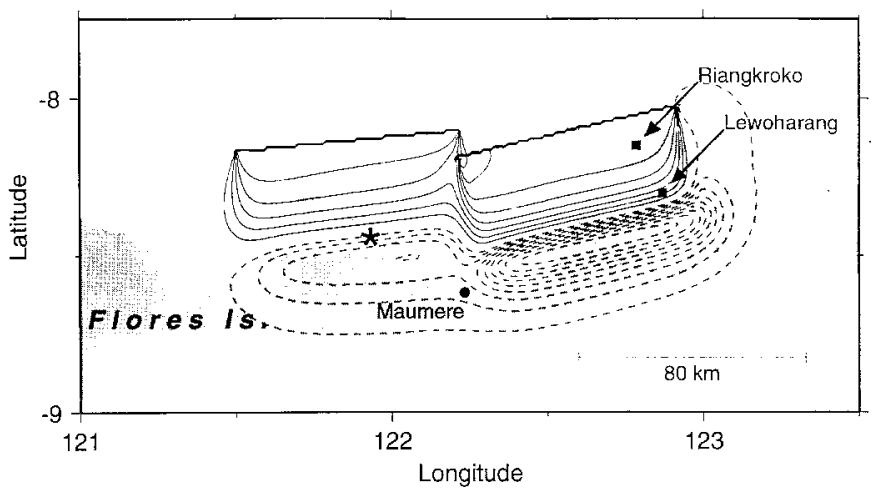

Figure 5

The vertical component of surface deformation estimated from the seismic inversion model. Contours of uplift (in $10 \mathrm{~cm}$ increments) are shown as solid curves, while contours of depression are shown as dashed curves. The surface projections of the two-fault planes may be seen where the uplift contours coalesce to form heavy lines. The epicenter (from the PDE) is shown by the asterisk. The city of Maumere is indicated, as well as the villages of Riangkroko and Leworahang. 
from this point at an azimuth of $80^{\circ}$ (the heavy line on the right). Since the strikes and dips determined from the inversion are slightly different, these two planes do not exactly meet at their edges.

Given these fault areas and the seismic moments determined in the inversion, and assuming the rigidity to be $3 \times 10^{11} \mathrm{dyne} / \mathrm{cm}^{2}$, the average slip on each fault plane should be $5.6 \mathrm{~m}$. However, preliminary tsunami models computed with this amount of slip for the first source, generated tsunami heights that were too large on the central and western parts of the affected area of Flores Island. Therefore, in modeling tsunami generation, we presume the slip for the first source to be $3.2 \mathrm{~m}$. This is the value assumed by YeH et al. (1993) in their initial model. An alternative would be to increase the area of the first fault. However, if the center of the fault is located at the hypocenter, this would result in significant tsunamis farther to the west than observed on Flores Island. Another alternative is to move both fault planes in a northerly or southerly direction, assuming that the hypocenter is either incorrect, or does not correspond to the bottom of the first fault plane. However, moving both planes either north or south by 5 minute increments (about $9 \mathrm{~km}$ ) also generates tsunami amplitudes that are too large. The reason for this may be seen in the contours of vertical surface deformation in Figure 5. The shallow reverse mechanism generates uplift shown by the solid contours, and depression shown by dashed contours. The area of zero vertical deformation lies along much of the coast, so if the planes are shifted the amplitude of deformation (either positive or negative) increases. Finally, we note that geodetic measurements at Maumere indicated subsidence of $15 \mathrm{~cm}$ (GONZÁLEZ et al., 1993), while the model indicates subsidence of slightly more than $20 \mathrm{~cm}$, which is in reasonable agreement with that measured.

From the surface deformation and bathymetry models, tsunami propagation is computed using a finite-difference method. We use both a linear model (SATAKE and KANAMORI, 1990) and a nonlinear model (SATAKE, 1995). In the linear model, tsunami amplitude is proportional to the amount of slip on the fault. In the nonlinear model, the tsunami amplitude is controlled by nonlinear terms and bottom friction, in addition to the fault slip. It turns out that with a reasonable value of bottom friction, the results are very similar for this event; the maximum tsunami heights predicted by the nonlinear model are only slightly smaller than those predicted by the linear model. This is because the ocean depth is quite large around Flores Island.

Computations were made for a total duration of 6 hours, with a time increment of $5 \mathrm{sec}$. Snapshots of the linear tsunami model for the first six one-minute intervals are shown in Figure 6. Here we see that the seafloor uplift, due to the two faults, causes a large tsunami wave to be generated within the first minute. As the wave propagates into deeper water to the north, the amplitude decreases. However, in the shallow water along the coast of Fores Island, and particularly within Hading Bay, large amplitude tsunami waves continue for several minutes. 

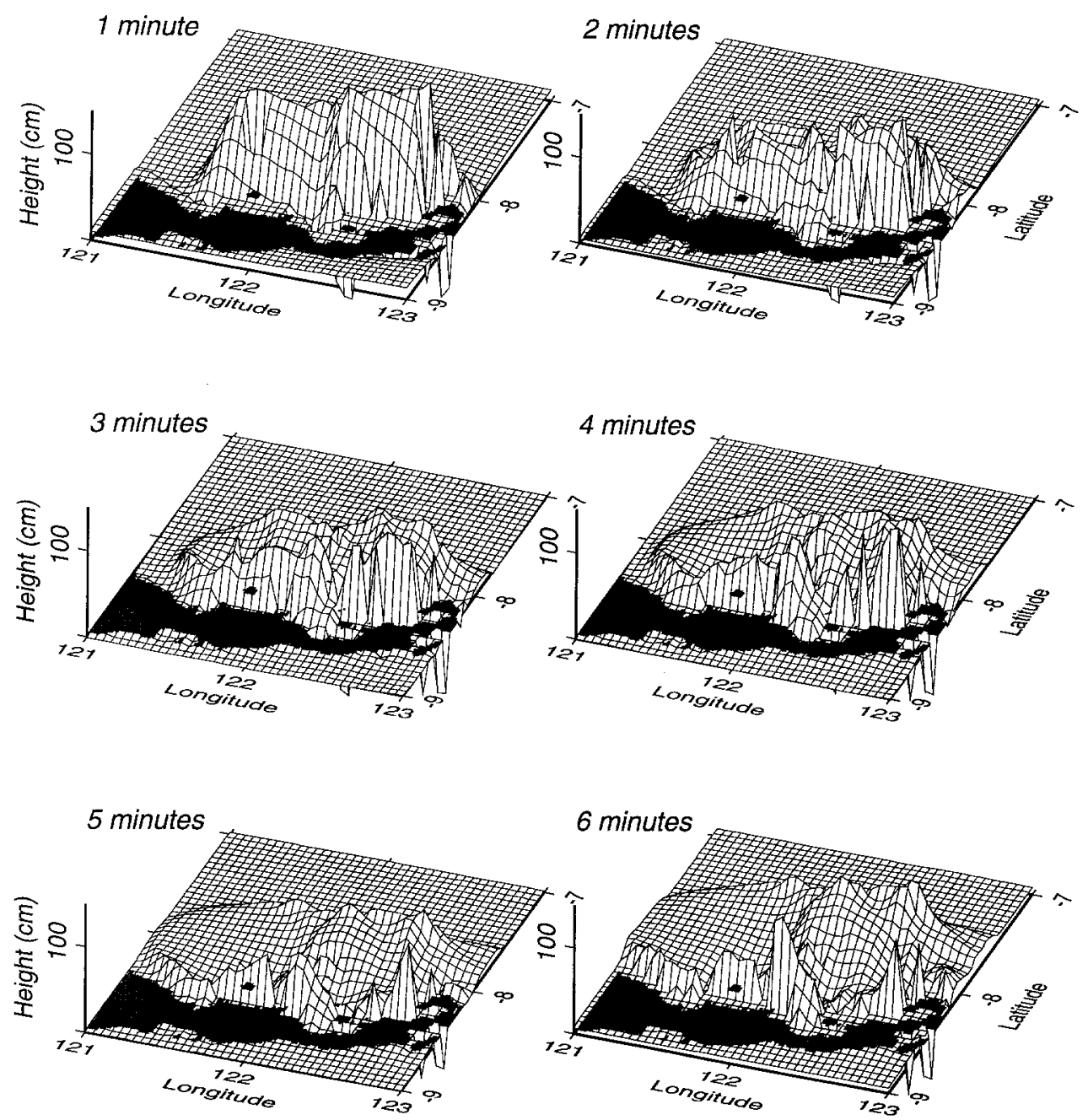

Figure 6

Snapshots of the first six minutes of tsunami propagation for the two-fault model. The large initial amplitude decreases rapidly as the tsunami moves into deeper water to the north, but remains large as shallow coastal areas are approached to the south. The wave meets Flores Island after three minutes, with large amplitudes (particularly near Maumere) continuing for minutes afterwards.

Tsunami waveforms were computed for the Palopo tide gauge station and for 37 sites on Flores Island and nearby small islands, where maximum tsunami runup measurements are available. At coastlines, total reflection is assumed in the computation (i.e., tsunami runup is not modeled directly). For these locations, we take the largest positive amplitude and multiply by two (the assumed tsunami runup amplification factor) in order to compare with the observed tsunami runup heights. A map comparing observed and computed tsunami runup heights is shown in 


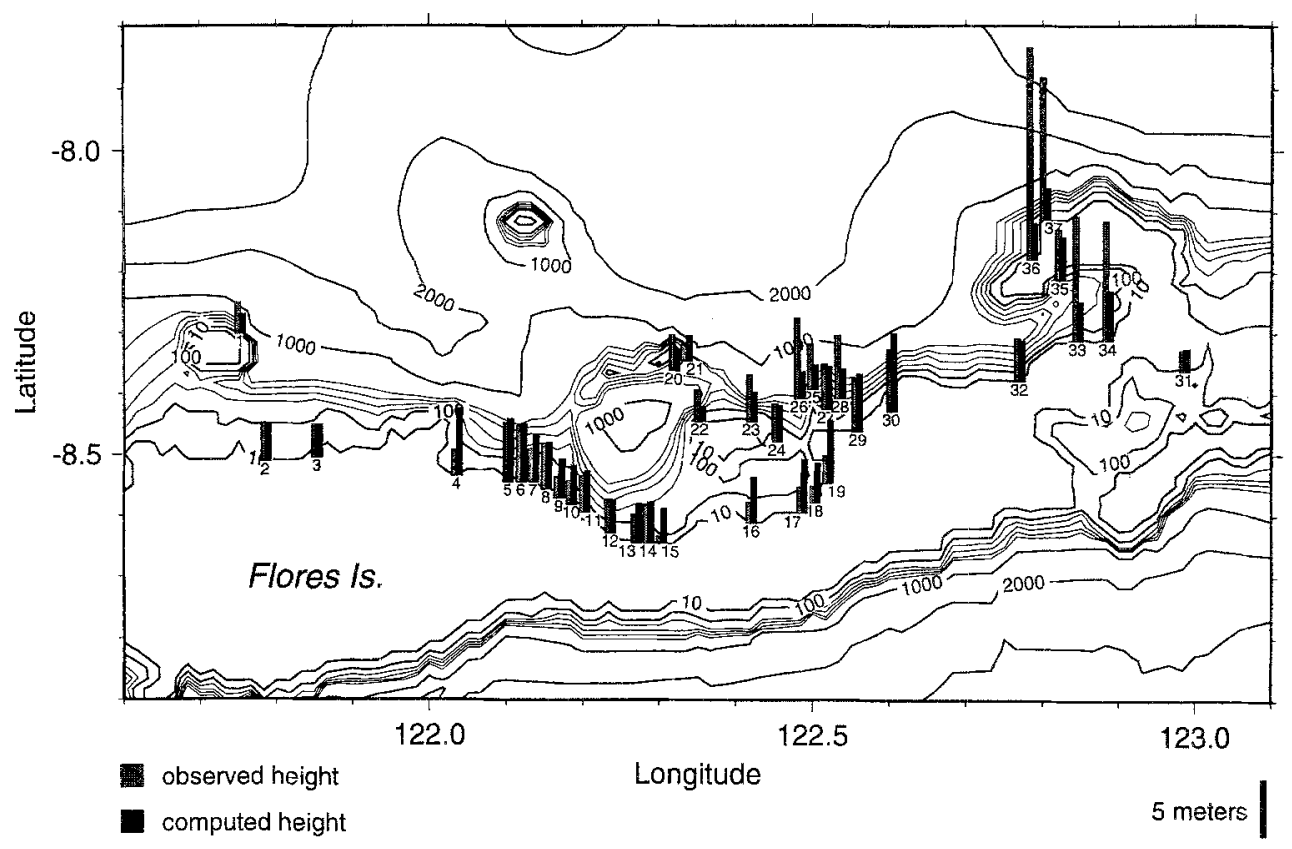

Figure 7

Bar graph showing observed (hatchured) and computed (solid) tsunami runup heights at various positions on and near Flores Island for the two-fault model. The location numbers and heights are listed in Table 4. A tsunami runup amplification factor of two is assumed for all locations. The model explains the observed tsunami runup heights well in the central and western portions of the affected area. However, it cannot explain the large observations near Leworahang (locations 33 and 34 ) and Riangkroko (locations 36 and 37).

Figure 7 (with locations and observed and predicted tsunami runup heights listed in Table 4). The results for the linear model, based on the two seismic sources, matches the tsunami runup heights on the central and western portion of the affected area of Flores Island quite well. However, this model substantially underpredicts the large tsunami runup heights measured at Riangkroko and Bunga on the northeastern peninsula (locations 36 and 37 in Figure 7), and at Waibalen and Uepadung, which are near Leworahang on the south edge of Hading Bay (locations 33 and 34).

A massive coastal slump was observed near Leworahang (YEH et al., 1993). For purposes of modeling tsunami generation, we may model this as a very large vertical displacement over a very small area. The height of the scarp produced is about $7.5 \mathrm{~m}$, and based on submerged coconut trees, the depth of the water immediately in front of the scarp is about $10 \mathrm{~m}$ (YEH et al., 1993), so we assume a vertical displacement of $17.5 \mathrm{~m}$ located entirely within one grid point (about $1.2 \mathrm{~km}$ ) at Leworahang. This unusual source will cause an unavoidable numerical dispersion in the finite-difference code. To investigate the effect of this error, we have also computed the tsunami generated by a vertical displacement of $10 \mathrm{~m}$ 
distributed over four grid points (approximately $5 \mathrm{~km}$ horizontal extent). The results are nearly identical, although the four-grid-point model may suffer from numerical dispersion as well. Physically, gravity waves from such a small source may not be modeled as long (shallow water) waves, but may be modeled as more dispersive deep water waves.

The largest observed tsunami runup, however, was at Riangkroko (with one measurement at $26 \mathrm{~m}$ !). A landslide with a horizontal extent of about $600 \mathrm{~m}$ was observed near this location (George Plafker, personal communication). Since the direction of fallen trees tend away from the landslide, it is reasonable to assume that large tsunami waves were generated by this landslide source. Another possible explanation is an anomalously large tsunami runup factor due to the topography of the area, which is influenced by a stream flowing into the sea. However, four different measurements gave an average tsunami runup height of $19.6 \mathrm{~m}$ at $\mathrm{Ri}$ angkroko, while $6 \mathrm{~km}$ away at Bunga the tsunami runup height was $12.3 \mathrm{~m}$. Lacking topographic data and appropriate programs for computing runup, we will presume a submarine slump by including a second single-grid-point slump source (also with a vertical dislocation of $17.5 \mathrm{~m}$ ) located at Riangkroko. The results for this combined faulting and slumping model are plotted on the map in Figure 8 and

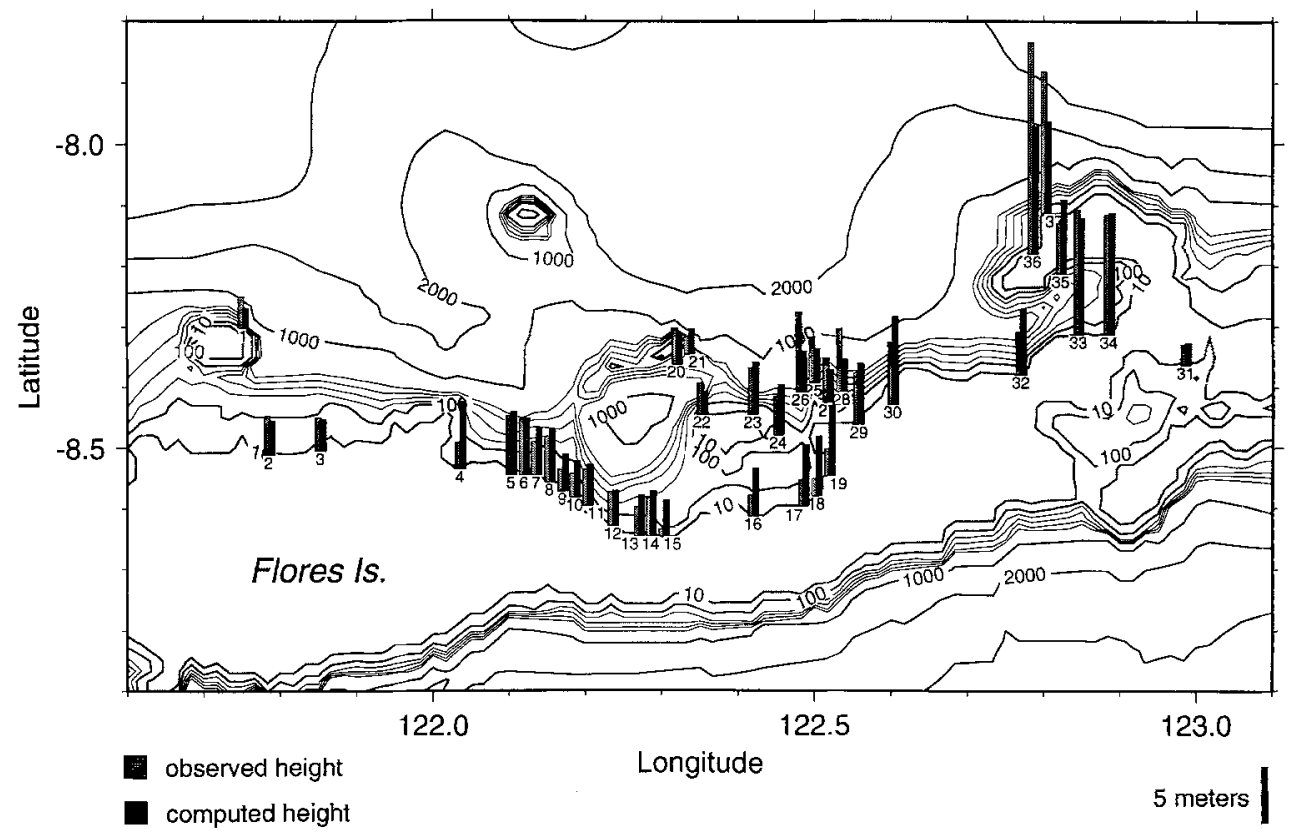

Figure 8

Bar graph showing observed (hatchured) and computed (solid) tsunami runup heights for the final model, which includes two faults and two slumps (one near Leworahang and one near Riangkroko). The heights are, once again, listed in Table 4. This model explains most of the observed tsunami runup heights, although the computed height at Riangkroko is still less than observed. 


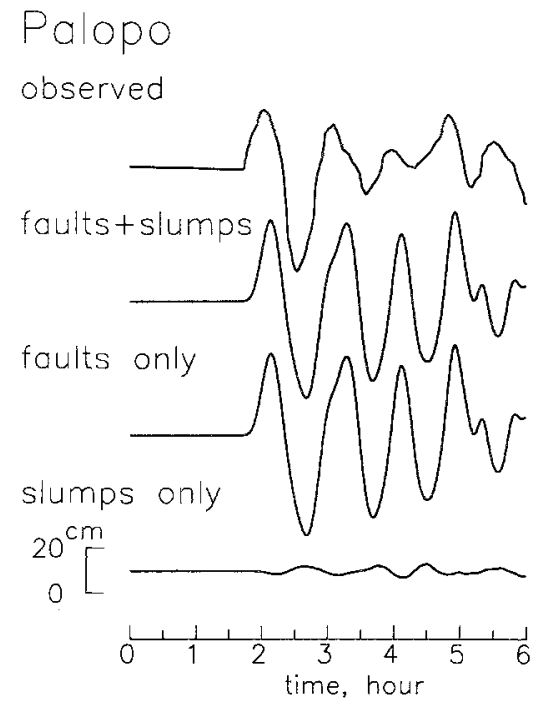

Figure 9

Observed and computed tide gauge records at Palopo. The observed waveform is shown on the top. The second trace is that computed for the final model. The third trace is that computed for the two-source model (without slumps). The bottom trace is that computed for a model consisting only of the two slumps. The slump sources have little influence on the computed waveform at Palopo. The two-fault model explains the observed waveform well, particularly in the first three half-cycles. The large later arrivals in the computed waveform limits the amplitude of slip on the second source.

listed in Table 4. The tsunami runup heights on the western and central portions of the affected area of Flores Island are, once again, well modeled. In fact, the slumping sources generate large tsunamis only in the immediate vicinity of the slump. The model explains the observed tsunami runup heights in Hading Bay (locations 33 and 34) very well, indicating that the coastal landslide near Leworahang was responsible for the large tsunamis experienced there. Our slumping source at Riangkroko also explains over half of the extremely large tsunami runup height observed there and at Bunga (locations 36 and 37). If a slumping source is responsible for the large amplitudes there, either a larger area of slumping or greater vertical displacement is required.

Finally, the most rigorous test of the tsunami models is the fit to the tide gauge record at Palopo. This is shown in Figure 9, with maximum and minimum tsunami wave amplitudes listed in Table 5. Due to the shallow coastal water around Palopo, we have chosen to display the tsunami waveforms computed with the nonlinear model, although the results are nearly identical for the linear model. Displayed at the top of the figure is the observed tide gauge record for the first six hours after the earthquake (digitized from GonzÁLEZ et al., 1993). Below this, and plotted on the same time and amplitude scales, are the computed tsunami waveforms for the final model, for the initial 2-fault model, and for the two slumping sources alone. 
Table 5

Observed and predicted tsunami amplitude at Palopo (latitude $-2.98^{\circ}$, longitude $120.22^{\circ}$ )

\begin{tabular}{lrrrrr}
\hline & \multicolumn{2}{c}{ Linear model } & \multicolumn{2}{c}{ Nonlinear model } \\
& Observed & 2 faults & +2 slumps & 2 faults & +2 slumps \\
\hline Maximum (cm) & 25.0 & 43.9 & 44.9 & 40.5 & 39.9 \\
Minimum (cm) & -46.6 & -46.8 & -47.6 & -44.2 & -43.1 \\
\hline
\end{tabular}

We see initially that the slumping sources have very little effect on the tsunami wave observed at such a large distance. The waveform for the final model is nearly identical to that for the two faulting sources. For the first three half-cycles, these fit the observed tide gauge record extremely well. If the slip were increased on either of the faults, whether in an attempt to explain the large tsunami runups on the eastern end of Flores Island, to reduce the assumed fault areas, or to be in better agreement with the seismic moment determined in the seismic inversion, the amplitude of the Palopo tsunami record could not be as well modeled. This is particularly true of the second seismic source which, perhaps due to slightly less complicated bathymetry along the path to Palopo (see Figure 2), is primarily responsible for the large-amplitude oscillations that continued for nearly four hours in the computed waveforms. Large amplitudes are observed at Palopo extending to six hours after the earthquake, but the amplitude of oscillation is not as large or consistent as in the computed waveforms. If the slip were increased on the second fault, these later oscillations would be even larger. With a more detailed bathymetric model around the Palopo tide gauge station, it may be possible to improve the later details of the computed tsunami waveforms. However, our final model, with two seismic sources and two slumping sources, provides a reasonable fit to the observed tide gauge record, given the bathymetric data available.

\section{Conclusions}

Inversion of teleseismic $P$ and $S H$ waves, as well as $P P$ waves at ranges up to $123^{\circ}$, indicates that the Flores Island earthquake occurred with reverse motion on a shallow-dipping fault with two distinct asperities. The centroid depth of both sources is quite shallow $(9 \mathrm{~km})$, certainly a contributing factor to the tsunami generation potential of this earthquake. The second source occurred $28 \mathrm{sec}$ after the first and is located to the east, although the spatial separation is poorly resolved. The inversion indicates a similar seismic moment for each source, with a moment magnitude for each of 7.8. The duration of each source is also similar $(28-30 \mathrm{sec})$, therefore using the relationship with seismic moment and source duration (COHN et al., 1982), the average stress drops for the first and second source are 49 and 37 bars, respectively. 
Using a detailed bathymetry model and estimating surface deformation from the seismic inversion results, we obtained linear and nonlinear models of tsunami generation and propagation. Using as observed data a single tide gauge record at Palopo (650 km away) and maximum tsunami runup heights measured on and near Flores Island, we find that the slip of the first source must be reduced (to $3.2 \mathrm{~m}$ ) in order to fit the tsunami runup heights on the western portion of the affected area of Flores Island. The slip of the second source cannot be substantially larger than $5.6 \mathrm{~m}$, or the predicted tsunami amplitude at Palopo will be too large. The two-source seismic model cannot explain the large tsunami runup heights measured near Leworahang on Hading Bay, or near Riangkroko on the northeast peninsula of Flores Island. A large coastal slump was observed at Leworahang, and a landslide was observed at Riangkroko. When we model these as point sources of vertical displacement, the tsunami runup heights near these locations are well modeled. It is clear that the two-source seismic model can explain the tsunami height observed at Palopo and the tsunami runup heights observed on most of Flores Island. However, the large tsunami runups observed near Leworahang and Riangkroko require localized, large secondary sources such as coastal or submarine slumps.

\section{Acknowledgements}

We would like to thank Frank González, Yoshinobu Tsuji and Fumihiko Imamura for providing information and data prior to publication. In addition, we appreciate the comments of two anonymous reviewers. Seismic data were obtained from the IRIS Data Management Center, and the figures were generated using GMT. This research was supported in part by the U.S. Geological Survey (grant 1434-93-G-2277) at SUNY Binghamton and by the National Science Foundation (grant EAR-9117800) at U. Michigan.

\section{REFERENCES}

BARKer, J. S., and LANGSton, C. A. (1981), Inversion of Teleseismic Body Waves for the Moment Tensor of the 1978 Thessaloniki, Greece, Earthquake, Bull. Seismol. Soc. Am. 71, 1423-1444.

BArker, J. S., and LANGSton, C. A. (1982), Moment Tensor Inversion of Complex Earthquakes, Geophys. J. Roy. Astr. Soc. 68, $777-803$.

Bırker, J. S., and LAngston, C. A. (1983). A Teleseismic Body-wave Analysis of the May 1980 Mammoth Lakes, California, Earthquakes, Bull. Seismol. Soc. Am. 73, 419-434.

BrCKers, J., and LAY, T. (1995), Very Broadhand Seismic Analysis of the 1992 Flores, Indonesia Earthuake $\left(M_{w}=7.9\right)$ : Observations on Back-arc Tectonic Setting and Tsunami Generation, $\mathbf{J}$. Geophys. Res., in press.

Cohn, S. N., Hong, T.-L., and Hflmberger, D. V. (1982), The Oroville Earthquakes: A Study of Source Characteristics and Site Effects, J. Geophys. Res. 87, 4585-4594.

Gild, R. R. (1976), Scaling Relations for Earthumake Source Parameters and Magnitudes, Bull. Seismol. Soc. Am. 66, 15011523. 
González, F., Sutisna, S., Hadi, P., Bernard, E., and Winarso, P. (1993), Some Observations Related to the Flores Island Earthquake and Tsunami. In Proc., Intl. Tsunami Symposium, TSUNAMI '93, 23-27 August 1993, Wakayama, Japan.

Imamura, F., and Kikuchi, M. (1994), Moment Release of the 1992 Flores Island Earthquake Inferred from Tsunami and Seismic Data, Sci. Tsunami Hazards 12, 67-76.

KanAmori, H., and ANDERSON, D. L. (1975), Theoretical Basis of Some Empirical Relations in Seismology, Bull. Seismol. Soc. Am. 65, 1073-1095.

KikUChI, M., and Kanamori, H. (1991), Inversion of Complex Body Waves - III, Bull. Seismol. Soc. Am. 81, 2335-2350.

LangSTON, C. A. (1981), Source Inversion of Seismic Waveforms: The Koyna, India, Earthquake of September 13, 1967, Bull. Seismol. Soc. Am. 71, 1-24.

Langston, C. A., and Helmberger, D. V. (1975), A Procedure for Modeling Shallow Dislocation Sources, Geophys. J. Roy. Astr. Soc. 42, 117-130.

OKaDA, Y. (1985), Surface Deformation due to Shear and Tensile Faults in a Halfspace, Bull. Seismol. Soc. Am. 75, 1135-1154.

Plafker, G., and WARD, S. N. (1992), Backarc Thrust Faulting and Tectonic Uplift along the Caribbean Sea Coast during the April 22, 1991, Costa Rica Earthquake, Tectonics 11, 709-718.

SATAKE, K. (1995), Linear and Nonlinear Computations of the 1992 Nicaragua Earthquake Tsunamis, Pure and Appl. Geophys., this issue.

Satake, K., and Kanamori, H. (1991), Abnormal Tsunamis Caused by the June 13, 1984, Torishima, Japan, Earthquake, J. Geophys. Res. 96, 19,933-19,939.

Satake, K., and TaniokA, Y. (1995), Tsunami Generation of the 1993 Hokkaido Nansei-oki Earthquake, Pure and Appl. Geophys., this issue.

Tsui, Y., and Matsutomi, H. (1993), Damages due to the tsunami. In The Report of the Field Survey of the Flores Island Earthquake-Tsunami of December 12, 1992 (ed. Tsuji, Y.) (in Japanese with English abstracts) pp. 70-87.

Tsuji, Y., Matsutomi, H., Imamura, F., Takeo, M., Kawata, Y., Matsuyama, M., Takahashi, T., SunAR.Jo and HARJADI, P. (1995), Damage of Coastal Villages due to the 1992 Flores Island Earthquake Tsunami, Pure and Appl. Geophys., this issue.

Yeh, H., Imamura, F., Synolakis, C., Tsuil, Y., Liu, P., and Shi, S. (1993), The Flores Island Tsunamis, EOS, Trans. Am. Geophys. Union 74(33), 369, 371-373.

(Received October 3, 1994, revised March 7, 1995, accepted March 14, 1995) 